\title{
Iodine and Selenium Contents in Skeletal Muscles of Red Deer (Cervus elaphus), Roe Deer (Capreolus capreolus) and Wild Boar (Sus scrofa) in the Czech Republic
}

\author{
† Jaroslav Kursa ${ }^{1}$, Ivan Herzig², Jan Trávníček ${ }^{1}$, Josef Illek³, Vlasta Kroupová1, \\ Śárka Fuksová ${ }^{4}$ \\ ${ }^{1}$ Department of Anatomy and Physiology of Farm Animals, Faculty of Agriculture, University of South \\ Bohemia in České Budějovice, Czech Republic \\ ${ }^{2}$ Department of Nutrition, Livestock Breeding and Hygiene, Faculty of Veterinary Hygiene and Ecology, \\ ${ }^{3}$ Ruminant Clinic, Faculty of Veterinary Medicine, University of Veterinary and Pharmaceutical Sciences Brno, \\ Czech Republic \\ ${ }^{4}$ Regional Veterinary Administration for West Bohemia, Plzeň, Czech Republic
}

Received June 30, 2009

Accepted April 6, 2010

\begin{abstract}
The objective of this study was to examine iodine and selenium contents in skeletal muscles of selected species of game animals living in regions with low iodine and selenium contents in the soil and water. Iodine content was determined in 66 samples of skeletal muscles of red deer cut out of the musculus gracilis, 32 samples and 27 samples from the same muscle of roe deer and wild boar, respectively. The shot game animals came from hunting grounds in western and southern regions of the Czech Republic and in Protected Landscape Area Sumava. In red deer muscles the average iodine content was $44.9 \pm 15.2 \mu \mathrm{g} \mathrm{I} \cdot \mathrm{kg}^{-1}$ wet weight with the range of 6.9 to $82.0 \mu \mathrm{g} \mathrm{I} \cdot \mathrm{kg}^{-1}$. The lower concentration in roe deer meat with the average $39.3 \pm 14.1 \mu \mathrm{g} \mathrm{I}^{\circ} \mathrm{kg}^{-1}$ and the range from 18.3 to $84.4 \mu \mathrm{g} \mathrm{I} \cdot \mathrm{kg}^{-1}$ may be due to differences between biotopes and food. The average iodine concentration in the musculus gracilis of wild boars was $55.9 \pm 27.0 \mu \mathrm{g}^{\circ} \mathrm{kg}^{-1}$ wet weight. Selenium content was determined in 22 samples of red deer, 51 samples of roe deer and 27 samples of wild boar skeletal muscles. The average values of selenium content in the meat of red deer, roe deer and wild boars were $16.2 \pm 8.4,36.9 \pm 16.6$ and $27.6 \pm 19.8 \mu \mathrm{g} \mathrm{Se} \cdot \mathrm{kg}^{-1}$ wet weight, respectively. All three species of game animals are characterised by low content and high variability of selenium concentration in meat with the minimum value $3.9 \mu \mathrm{g}$ and maximum value $83.3 \mu \mathrm{g} \cdot \mathrm{kg}^{-1}$ wet weight. The study brings new data on iodine and selenium content in the muscle of game animals in the Czech Republic.
\end{abstract}

Trace elements, game animals, meat, thyroid gland, season

Analytical determination of the content of trace elements in biological materials for diagnostic purposes and for the evaluation of their reserves in the organism is applicable in humans and in animals; reference values for game animals need to be established (Wilson and Grace 2002; Allen and Ullrey 2004). Functional requirements predetermine the preferential accumulation of iodine in the thyroid gland. The iodine (I) content in skeletal muscles is significantly determined by the animal species. A higher iodine content in the muscles of carnivores is influenced e.g. by the type of food. The skeletal muscle of farm and game animals living withouth supplemental sources of iodine contains 100-300 $\mu \mathrm{g}$ ${\mathrm{I} \cdot \mathrm{kg}^{-1}}^{-1}$ The relatively lowest amount of iodine is presented in the meat of sheep with higher amounts in the meat of pigs, cattle and poultry (Anke 2007).

Essential need of selenium and its efficiency in the prevention and therapy of some diseases in human population (Kvíčala et al. 2003) and in farm animals (Enjalbert et al. 1999; Pavlata et al. 2001) has been studied, including its role in human nutrition (Anke 2007).

In the years 1981-1982, Galgan and Frank (1995) collected liver tissues from moose in 14 regions in Sweden. The median of selenium (Se) concentration in the liver was $0.15 \mu \mathrm{g} \cdot \mathrm{kg}^{-1}$ and the mean $0.25 \pm 0.29 \mathrm{mg} \cdot \mathrm{kg}^{-1}$ wet weight. The results indicate that moose

Address for correspondence:

Jan Trávníček

University of South Bohemia in České Budějovice, Faculty of Agriculture

Department of Anatomy and Physiology of Farm Animals

Phone: +420387772621

Fax: +420 387772621

E-mail: travnic@zf.jcu.cz

Studentská 13, České Budějovice, Czech Republic

http://www.vfu.cz/acta-vet/actavet.htm 
is useful for monitoring the amount of selenium available for wild grazing animals, and confirm that the Swedish environment is poor in selenium. Grace and Wilson (2001) concluded that in New Zealand Co, Se and I deficiencies in deer are of lesser importance than deficiency of $\mathrm{Cu}$. In western Norway, liver samples from 245 wild red deer were analysed for Se concentration (Vikoren et al. 2005). The median concentration of Se was $0.09 \mu \mathrm{g} \cdot \mathrm{g}^{-1}$ with range $0.04-1.0 \mu \mathrm{g} \cdot \mathrm{g}^{-1}$ of wet weight. Concentration of Se showed a significant geographic variation and significant differences in age groups with the highest concentrations in adults. Adult males had significantly higher Se concentrations than females. Flueck (1994) studied the role of Se supplementation on black-tailed deer in northern California. Whole blood selenium concentrations of non-supplemented animals were low $\left(24 \mu \mathrm{g} \cdot \mathrm{kg}^{-1}\right)$. There were no differences in Se concentrations among sexes, ages and seasons. Supplements of Se increased pre-weaning fawn survival. The hypothesis that free-ranging wild ruminants are not susceptible to trace mineral deficiencies because of adaptations to deficiencies over geological time, was not supported. In southern Iceland, liver selenium concentrations varied between regions, farmed red deer had a higher Se concentration than feral deer (Tremain-Boon et al. 2002). Concentration of Se was measured in skeletal muscle of elk, mule, deer, bison, and cattle (Medeiros et al. 1993). In game animals, the samples did not differ in Se concentration but contained more Se than cattle. The concentration of Se was not affected by the type of muscle and sex. Holben (2002) documented that weight of male deers did not affect the Se content in meat. Hein et al. (1994) tested free-ranging ungulates in Washington State and found that Se concentrations in blood vary among elk herds. Bighorn sheep, mule deer, and moose have generally lower values of Se compared to domestic livestock. Selenium content in meat was studied in the Czech Republic by Koutník and Ingr (1998).

The aim of this study was to examine iodine and selenium contents in skeletal muscles of some species of game animals living in the Czech Republic and thus recommend the share of the meat of game animals as a source of both elements in human nutrition.

\section{Materials and Methods}

Iodine and selenium contents were tested in samples of the musculus gracilis of red deer (Cervus elaphus), roe deer (Capreolus capreolus) and wild boar (Sus scrofa) The animals were shot during hunting season in western and southern regions of the Czech Republic and in Protected Landscape Area Sumava. The time sequence of sample collections was given by the periods of permitted hunting law stipulated by Decree No. 242/2002 of the Ministry of Agriculture Czech Republic, except for several red deer kept on farms. Monitoring was done in two periods. The first period was from autumn to winter (September 2004-January 2005) when 44 samples of red deer meat were obtained. The second period was summer (May-September 2005) when 22 samples of red deer meat, 51 samples of roe deer meat and 27 samples of wild boar meat were collected. The muscle samples (100 g wet weight) were cut out and stored at a temperature of $-18{ }^{\circ} \mathrm{C}$ until their laboratory analyses.

The concentration of iodine in muscles was measured by a spectrophotometric method according to SandellKolthoff after the alkaline burning of the sample (Bednár et al. 1964). Selenium content in muscles was measured with a UNICAM 939 AA spectrometer after microwave mineralisation when the hydride technique of AAS was applied (Pechová et al. 2005). The final concentrations of iodine and selenium are given in $\mu \mathrm{g}^{\mathrm{kg}} \mathrm{kg}^{-1} \mathrm{of}$ wet weight (fresh tissue).

The region's influence on the iodine content in the muscles was assessed in the red deer hunted in a period of September 2004-January 2005 and its influence on the selenium content was assessed in wild boars in a period of May 2005-September 2005.

Data were statistically analyzed by ANOVA Tukey's test (STATISTICA CZ, version 7).

\section{Results and Discussion}

This study is based on previous data concerning the iodine and selenium saturation of farm animals (Kursa and Kroupová 1975; Trávníček et al. 2007), the iodine content in foods of animal origin (Herzig et al. 2005; Trávníček et al. 2006) and records of goitre in calves, lambs, foals and kids (Kursa et al. 1997). 
Table 1. Iodine content in skeletal muscles of red deer in various year seasons

\begin{tabular}{|l|c|c|c|r|c|c|}
\hline \multirow{2}{*}{ Period } & \multirow{2}{*}{$\mathrm{n}$} & \multicolumn{5}{|c|}{ Iodine $\mu \mathrm{g} \cdot \mathrm{kg}^{-1}$ wet weight } \\
\cline { 3 - 8 } & & $\overline{\mathrm{x}}$ & $\mathrm{SD}$ & $\mathrm{Min}$. & \multicolumn{1}{c|}{ Max. } & Median \\
\hline September 2004 - January 2005 & 44 & 45.1 & 12.3 & 22.4 & 73.0 & 42.7 \\
\hline May 2005 - September 2005 & 22 & 44.6 & 21.5 & 6.9 & 82.0 & 43.0 \\
\hline Total & 66 & 44.9 & 15.2 & 6.9 & 82.0 & 43.1 \\
\hline
\end{tabular}

Table 2. Iodine content in skeletal muscles of red deer from various areas of the Czech Republic

\begin{tabular}{|l|c|c|c|}
\hline \multirow{2}{*}{ Area } & \multirow{2}{*}{$\mathrm{n}$} & \multicolumn{2}{|c|}{ Iodine $\mu \mathrm{g} \cdot \mathrm{kg}^{-1}$ wet weight } \\
\cline { 3 - 4 } & & $\overline{\mathrm{x}}$ & $\mathrm{SD}$ \\
\hline Protected Landscape Area Šumava & 22 & $38.4^{\mathrm{a}}$ & 7.9 \\
\hline Southern region & 6 & $48.2^{\mathrm{b}}$ & 9.0 \\
\hline Western region & 16 & $53.2^{\mathrm{c}}$ & 12.7 \\
\hline Total & 44 & 45.1 & 12.3 \\
\hline
\end{tabular}

a:c $P<0.01 ;$ a:b $P<0.05$

Table 3. Seasonal differences in the iodine content of red deer skeletal muscles in the same localities of Protected Landscape Area Sumava

\begin{tabular}{|l|c|c|}
\hline \multirow{2}{*}{ Locality } & \multicolumn{2}{|c|}{ Iodine $\mu \mathrm{g} \cdot \mathrm{kg}^{-1}$ wet weight } \\
\cline { 2 - 3 } & September 2004 - January 2005 & May 2005 - September 2005 \\
\hline Mlynářovice & 42.7 & 50.6 \\
\hline Borová Lada & 33.8 & 37.0 \\
\hline České Žleby & 40.3 & 40.7 \\
\hline Plesny & 48.5 & 41.5 \\
\hline Modrava & 68.3 & 38.3 \\
\hline Srní & 81.0 & 52.0 \\
\hline Práśily & 64.1 & 55.5 \\
\hline Křemelná & 54.5 & 46.7 \\
\hline $\bar{x}$ & 54.1 & 45.3 \\
\hline SD & 16.0 & 6.9 \\
\hline
\end{tabular}

The mean content of iodine in 66 samples of red deer skeletal muscles reached the value 44.9 $\pm 15.2 \mu \mathrm{g} \mathrm{I} \cdot \mathrm{kg}^{-1}$ wet weight at a high variability of data (Table 1). The lowest iodine concentration of $38.4 \pm 7.9 \mu \mathrm{g}$ $\mathrm{I} \cdot \mathrm{kg}^{-1}$ wet weight was recorded in red deer from Protected Landscape Area Šumava and the highest concentration 53.2 $\pm 12.7 \mu \mathrm{g} \mathrm{I} \cdot \mathrm{kg}^{-1}$ wet weight was measured in red deer from the western region (Table 2). The analyses of iodine content in

skeletal muscles of game animals indicated significant interspecies (Table 4) and regional (Table 3) differences.

The lower concentration of iodine in roe deer meat compared to red deer meat may be due to different characteristics of biotopes of the two species, hence from differences in the food composition. The roe deer are more fixed to farmed areas, grazing on the farm crops such as oilseed rape with the content of goitrogenic glucosinolates (Kursa et al. 2000) or other crops including intensively fertilised forage crops with nitrates that have the same effects (Anke 2007).

The significantly higher iodine content in skeletal muscles of wild boars, $55.9 \pm 27.0 \mu \mathrm{g}$ $\mathrm{I} \cdot \mathrm{kg}^{-1}$ wet weight (Table 4), apparently reflects their varied food. The wild boar is a typical omnivore. It may be the component of food that influences the higher intake of iodine

Table 4. Iodine content in skeletal muscles of roe deer and wild boars

\begin{tabular}{|l|c|c|c|c|c|c|c|}
\hline \multirow{2}{*}{ Species } & \multirow{2}{*}{ Season } & \multirow{2}{*}{$\mathrm{n}$} & \multicolumn{5}{|c|}{ Iodine $\mu \mathrm{g} \cdot \mathrm{kg}^{-1}$ wet weight } \\
\cline { 5 - 9 } & & & $\overline{\mathrm{x}}$ & $\mathrm{SD}$ & $\mathrm{Min}$. & Max. & Median \\
\hline Roe deer & May 2005 - September 2005 & 32 & $39.3^{\mathrm{a}}$ & 14.1 & 18.3 & 84.4 & 37.2 \\
\hline Wild boars & May 2005 - September 2005 & 27 & $55.9^{\mathrm{b}}$ & 27.0 & 13.1 & 103.8 & 57.0 \\
\hline
\end{tabular}

a:b $P<0.01$ 
(Anke 2007). The meat of wild boars contains 100\% more iodine than the identical muscle of slaughter pigs as reported by Herzig et al. (2005).

Based on the anamnestic data acquired from hunting grounds and localities of sample collections, it is possible that the composition of additional food was enriched also with concentrates. The variety of supplied food indicates possible intake of iodine by game animals from these sources and more or less eliminates the direct dependence of game animals on the plant food of local origin. The mineral component of additional food was mostly rock salt and licks for game animals or vitamin and mineral supplements with trace elements including iodine were reported irregularly. Nevertheless, the limit low values of iodine in the milk of dairy cows have been recorded in these localities previously (Kursa et al. 1997).

The mean content of selenium $\left(36.9 \pm 16.6 \mu \mathrm{g} \mathrm{kg}^{-1}\right)$ in roe deer muscles (Table 5) exceeded the Se content in the meat of red deer $\left(16.2 \pm 8.4 \mu \mathrm{g} \mathrm{kg}^{-1}\right)$ as well as that of wild boar $(27.6$ $\left.\pm 19.8 \mu \mathrm{g} \mathrm{Se} \cdot \mathrm{kg}^{-1}\right)$. Similarly as iodine, the lowest mean content of selenium was measured in the meat of red deer in the localities of Protected Landscape Area Šumava (13.6 $\mu \mathrm{g}$ $\left.\mathrm{Se} \cdot \mathrm{kg}^{-1}\right)$. The results of selenium monitoring in game animals are comparable with the low values determined in muscles of cattle in these localities by the same chemical method by Pavlata et al. (2001). These low selenium values indicate selenium deficiency in clinical form in cattle and sheep in Šumava localities where selenium concentration was also low in the plants (Kursa and Kroupová 1975).

Table 5. Selenium content in skeletal muscles of game animals

\begin{tabular}{|l|c|c|c|c|c|c|}
\hline \multirow{2}{*}{ Period } & \multirow{2}{*}{$\mathrm{n}$} & \multicolumn{5}{|c|}{ Iodine $\mu \mathrm{g} \cdot \mathrm{kg}^{-1}$ wet weight } \\
\cline { 3 - 8 } & & $\overline{\mathrm{x}}$ & $\mathrm{SD}$ & \multicolumn{1}{c|}{ Min. } & Max. & Median \\
\hline Red deer & 22 & $16.2^{\mathrm{a}}$ & 8.4 & 7.6 & 38.8 & 12.8 \\
\hline Roe deer & 51 & $36.9^{\mathrm{b}}$ & 16.6 & 13.6 & 83.3 & 34.3 \\
\hline Wild boars & 27 & $27.6^{\mathrm{c}}$ & 19.8 & 3.9 & 72.6 & 21.0 \\
\hline
\end{tabular}

a:b $P<0.01$, a:c, b:c, $P<0.05$

In conclusion, our study brings new data on iodine and selenium contents in the muscle of 144 game animals from the territory of the western, central and southern regions of the Czech Republic. Central Europe is a territory with low iodine contents in the soil and water, with accidental intake of both trace elements from mineral feeding and mixtures. These results indicate the deficieny risk of iodine and selenium in these regions of Czech Republic.

\section{Obsah jódu a selenu v kosterní svalovině jelení (Cervus elaphus), srnčí (Capreolus capreolus) a černé (Sus scrofa) zvěře v České republice}

Studie se zabývá zhodnocením obsahu jódu a selenu v kosterní svalovině lovné zvěře žijící v oblastech s nízkým obsahem jódu a selenu v půdě a vodě. Zviŕrata pocházela $\mathrm{z}$ honiteb v západočeském a jihočeském regionu a z Chráněné krajinné oblasti Śumava. Obsah jódu byl stanoven v kosterní svalovině musculus gracilis u 66 jelenů (Cervus elaphus), 32 srnců (Capreolus capreolus) a 27 divokých prasat (Sus scrofa). Ve svalovině jelenů byl zjištěn průměrný obsah jódu 44,9 $\pm 15,2 \mu \mathrm{g} \mathrm{I} \cdot \mathrm{kg}^{-1} \mathrm{~s}$ rozpětím od 6,9 do $82,0 \mu \mathrm{g} \mathrm{I} \cdot \mathrm{kg}^{-1}$. Nižší koncentrace jódu v srnčím mase s průměrem $39,3 \pm 14,1 \mu \mathrm{g} \mathrm{I} \cdot \mathrm{kg}^{-1}$ a rozpětím od 18,3 do $84,4 \mu \mathrm{g} \mathrm{I} \cdot \mathrm{kg}^{-1}$ může souviset s rozdílnými biotopy a odlišným složením potravy. Průměrná koncentrace jódu v kosterní svalovině divokých prasat byla $55,9 \pm 27,0 \mu \mathrm{g} \cdot \mathrm{kg}^{-1}$.

Obsah selenu byl stanoven v kosterní svalovině 22 jelenů $\left(16,2 \pm 8,4 \mu \mathrm{g} \mathrm{Se} \cdot \mathrm{kg}^{-1}\right), 51$ srnců $\left(36,9 \pm 16,6 \mu \mathrm{g} \mathrm{Se} \mathrm{kg}^{-1}\right)$ a 27 divokých prasat.(27,6 $\left.\pm 19,8 \mu \mathrm{g} \mathrm{Se} \cdot \mathrm{kg}^{-1}\right)$. U všech tři druhů zvěře byl zjištěn nízký obsah selenu a jeho vysoká variabilita $\mathrm{s}$ minimem 
$8,3 \mu \mathrm{g}$ a maximem $83,3 \mu \mathrm{g} \mathrm{Se} \cdot \mathrm{kg}^{-1}$. Studie přináší nové údaje o obsahu jódu a selenu ve svalovině lovné zvěře v Ceské republice.

\section{${ }^{\dagger}$ In memoriam Prof. MVDr. Jaroslav Kursa, DrSc.}

\section{Acknowledgements}

Supported by the Ministry of Education, Youth and Sports (Grant No. MSM 6007665806) and the National Agency for Agricultural Research (Grant No. 1B44013/2004).

\section{References}

Allen ME, Ullrey DE 2004: Relationships among nutrition and reproduction and relevance for wild animals. Zoo Biol 23: 475-487

Anke M 2007: Iod. In: Dunkelberg H, Gebel T, Hartwig A (Hrsg) Handbuch der Lebensmitteltoxikologie Belastungen, Wirkungen, Lebensmittelsicherheit, Hygiene (In German). Wiley-VCH Verlag GmbH q Co. KgaA, Weinheim, pp. 2317-2379

Bednár J, Röhling S, Vohnout S 1964: A contribution to determination of protein iodine in the serum (In Czech). Ceskoslov Farm 13: 203-209

Enjalbert F, Lebreton P, Salat O, Schelcher F 1999: Effects of pre- or post-partum selenium supplementation on selenium status in beef cows and their calves. J Anim Sci 77: 223-229

Flueck WT 1994: Effect of trace-elements on pulation-dynamicsselenium deficiency in free-ranging black-tailed deer. Ecology 75: 807-812

Galgan V, Frank A 1995: Survey of bioavailable selenium sweden with the moose (Alces-Alces L.) as monitoring animal. Sci Total Environ 172: 37-45

Grace ND, Wilson PR 2001: A review of tissue reference values to assess the trace elements status of farmed red deer. New Zeal Vet J 49: 126-132

Hein RG, Talcott PA, Smith JL, Myers WL 1994: Blood selenium values of selected wildlife populations in Washington. Northwest Sci 67: 431-433

Herzig I, Trávníček J, Kursa J, Kroupová V 2005: The content of iodine in pork. Vet Med- Czech 12: 521-525

Holben DH 2002: Selenium content of venison, squirrel, and beef purchased or produced in Ohio, a low selenium region of the United States. J Food Sci 67: 431-433

Koutník V, Ingr I 1998: Fleisch als selenquelle in der menschlichen Ernährung (In German). Fleischwirtschaft 78: $534-536$

Kursa J, Kroupová V 1975: Selenium content in cattle fur in incidence areas of nutritional muscle dystrophy (In Czech). Vet Med-Czech 20: 275-281

Kursa J, Herzig I, Kroupová V, Kratochvíl P, Trávníček J 1997: Consequence of iodine deficiency in cattle in some regions of the Czech Republic. Scientia Agric Bohem 28: 105-107

Kursa J, Trávníček J, Rambeck WA, Kroupová V, Vítovec J 2000: Goitrogenic effects of extracted rapeseed meal and nitrates in sheep and their progeny. Vet Med-Czech 45: 129-140

Kvíčala J, Zamrazil V, Jiránek V 2003: Selenium status of inhabitants of region Jablonec, Czech Republic. Trace Elem Electrolytes 20: 83-88

Medeiros LC, Belden RP, Williams ES 1993: Selenium content of bison, elk and mule Deer. J Food Sci 58: $731-733$

Pavlata L, Pechová A, Bečvář O, Illek J 2001: Selenium status in cattle at slaughter: analyses of blood, skeletal muscle and liver. Acta Vet Brno 70: 277-284

Pechova A, Pavlata L, Illek J 2005: Blood and tissue selenium determination by hydride generation atomic absorption spectrophotometry. Acta Vet Brno 74: 483-490

Trávníček J, Kroupová V, Herzig I, Kursa J 2006: Iodine content in consumer hen eggs. Vet Med-Czech 51: 93-100

Trávníček J, Písek L, Herzig I, Doucha J, Kvíčala J, Kroupová V, Rodinová H 2007: Selenium content in the blood serum and urine of ewes receiving selenium-enriched unicellular alga Chlorella. Vet Med-Czech 52: 42-48

Tremain-Boon SG, Hart JCA, Wilson PR, Lopez-Villalobos N 2002: Liver, copper, selenium and vitamin B-12 concentrations in farmed and feral red deer (Cervus elaphus). New Zeal Vet J 50: 111-114

Vikoren T, Bernhoft A, Waaler T, Handeland K 2005: Liver concentrations of copper, cobalt and selenium in wild Norwegain red deer (Cervus elaphus). J Wildlife Dis 41: 569-579

Wilson PR, Grace ND 2002: Trace element metabolism, dietary requirements, diagnosis and prevention in deer. New Zeal Vet J 50: 252-259 
